\title{
HISTORY OF THE REBEL MUSTER ROLL CAPTURED AT PINE BLUFF, ARKANSAS
}

\author{
By William H. Craven
}

Sergeant Company A, Seventh Missouri Volunteer Cavalry

Our three years of enlistment expired August 9, 1864, and on the 17th Lieutenant Grove, in command of fourteen men of Company $A$ and twelve of Company B, Seventh Missouri Volunteer Cavalry left Pine Bluff, Arkansas, at daylight for the purpose of making a secret march of thirty-two miles south to a mill, as General Clayton was anxious to know whether the Rebels were operating it.

We were guided by a native by the name of Columbus Marr, who lived in the neighborhood of the mill. He was loyal to the core and as brave a man as ever straddled a horse. There were five brothers and Lum, as we called him, if I remember right, the third. About noon we stopped to feed and rest our horses back of a field where the guide's mother, a widow, lived, and about three miles from the mill. As soon as our horses were rested we mounted and started for the mill, through the timber, as we had followed no road all day. We had not gone far until we could hear the throbbing of the engine. We went within about eighty rods of the mill when the Lieutenant concealed the command in the thicket and gave us orders to remain quiet until he should return. He and the guide left us and it made us a little nervous as we could plainly hear the Johnnies working the mill.

In about an hour they returned, having gone inside the Rebel camp to a house which was not more than two hundred yards from the mill and was occupied by a Union family. And, as our guide was personally acquainted with the family and knew he could trust them, he had one of the girls go to the mill under the ruse of having some milling done and get all the information she could in regard to the location of their camp and the number of Confederate soldiers there, which she did with accuracy. The Lieutenant called us around him. "Now, boys," he said, "General Clayton sent me out here to find out whether or not the Rebels were running the mill, which they are; thẹre are one hun- 
dred men running and guarding it; there are seventy now at the mill and thirty on a scout between here and Pine Bluff and have started since noon. Two miles south of the mill is their main camp, occupied by four thousand infantry and cavalry with two sections of artillery. Now, I have fulfilled my mission and it is for you to say whether we go any farther."

A tall, lank fellow by the name of Nicols straightened himself up and said, "We don't want to use ourselves up like we have today without getting one shot." "All right," said the Lieutenant, "mount your horses." We were now about eighty rods northeast of the mill and their camp was two or three hundred southwest. We made a circuit until we were almost west of their camp and about two hundred yards from it. Then we halted and the Lieutenant told Sergeant Smith of Company B to take twelve men of his company and charge the tent and he would take the fourteen from Company $A$ and charge the mill, and gave me orders to take the left of Company $A$ and not come into the mill yard until all of the men were in.

The Rebels were taken by complete surprise and did not discover our presence until Sergeant Smith with his squad rode into their camp and demanded their surrender and opened fire on them. Those that did not surrender took to the woods and left their horses just as they were in camp as they were neither bridled nor saddled. And the parties who were running the mill rushed out to see what the commotion was only to find the mill yard in possession of Company A. Some surrendered, others started to run, which was the wrong thing to do as they exposed themselves to the fire of our revolvers.

The captain in command of the Confederates, by the name of Henry, had been captured at Arkansas Post some time before and had been exchanged. He had just rode in from the main camp and might have made his escape had he known the situation; but he just sat on his horse and was being exposed to the fire from our boys. As soon as I got into the yard and saw that he had surrendered I called to him to dismount or he would be killed, which order he was not long in obeying.

It was now about five o'clock in the evening and a heavy rainstorm was brewing, which I have always thought was our salvation. Thẹ Lięutenanant called ụs together and gave us ordẹrs to set 
fire to their camp, get all the horses ready, detail a guard for the prisoners and be ready to march in the quickest time possible. I gathered up a firebrand out of their camp fire and started in the first tent in the line and kicked up the straw and applied the torch and was ready to go out again when I saw an old fashioned pair of saddle bags, the same as the frontier Methodist preachers used on their circuits. My curiosity was aroused to know what it contained, so I rescued it from the fire and threw it across my saddle and proceeded to help gather up the horses.

In a few moments we were on the march and by this time the rain was falling in torrents. The Lieutenant, instead of starting toward the Bluff, started on the road to the main Rebel camp but only followed it until we were out of sight of the houses that surrounded the mill and then took to the woods again. We made another circuit back around the mill and struck the Bluff road three or four miles north of the mill, getting there just at dark. We got into Pine Bluff the next morning about one o'clock. We led in sixty-three horses, twelve or fourteen prisoners, among them Captain Henry, their commander, with no loss to our command except some scratches from the limbs of trees we came in contact with. When I opened the saddle bags I had in my possession an old undershirt, which was inhabited, and the Muster Roll. This is a partial history of the scout in which it was captured.

The Hamilton Freeman has closed its seventh year, and is making leaves for a new volume. It was started by Charles Aldrich, who, by the way, is a born editor for whom there is no happiness in this life outside of a newspaper. $\mathrm{He}$ is one of the best paragraphists in America. The present editor of the Freeman, Mr. Ballou, understands his business thoroughly.-Daily State Register, Des. Moines, June 7, 1866. (In the Newspaper Division of the Historical, Memorial and Art Department of Iowa.) 
Copyright of Annals of Iowa is the property of State of Iowa, by \& through the State Historical Society of Iowa and its content may not be copied or emailed to multiple sites or posted to a listserv without the copyright holder's express written permission. However, users may print, download, or email articles for individual use. 